\section{Atypical Symptoms of Cold Damage to Pecan}

\author{
Bruce W. Wood ${ }^{\mathbf{1}}$ and Charles C. Reilly \\ U.S. Department of Agriculture, Agricultural Research Service, Southeastern \\ Fruit and Tree Nut Research Laboratory, Byron, GA 31008-0087
}

Additional index words. Carya illinoinensis, cold injury, fruiting stress, physiology, root starvation, nutrient elements, growth, death, alternate bearing

\begin{abstract}
Bearing pecan [Carya illinoinensis (Wangenh.) K. Koch] trees overly stressed by crop load and premature autumn defoliation either died or were severely damaged by $-3^{\circ} \mathrm{C}$ in mid-November. Orchard damage was associated with death of tree roots during the dormant season. Exposure of stressed trees to $-5^{\circ} \mathrm{C}$ in mid-March produced an atypical, but distinct, bottom-to-top-of-canopy gradient in bud death and reduced growth of shoots and foliage that was consistent with the pattern of reduced carbohydrate reserves of associated support shoots. Additionally, the foliage of damaged trees contained higher concentrations of $\mathrm{N}, \mathrm{P}, \mathrm{K}, \mathrm{Ca}, \mathrm{Mg}, \mathrm{Mn}, \mathrm{Fe}$, and $\mathrm{B}$. Trees did not exhibit traditional symptoms of cold damage, thus these findings extend cold injury diagnostic criteria to include both root and tree death during the dormant season and also a distinct gradient in shoot death during early spring. Damage by cold appears to be preventable by avoiding excessive tree stress due to overcropping and premature defoliation.
\end{abstract}

Because pecan trees and orchards often survive for $>100$ years, they are susceptible to damage by "severe infrequent disturbances" (SIDs) — such as tornados, hurricanes, ice storms, floods, droughts, winter cold, or outbreaks of pests (Dale et al., 1998). Cold damage is one of the most common SIDs affecting pecan. Its impact is influenced by factors such as cultivar (Cochran 1930; Smith et al., 1993; Sparks and Payne, 1978; Sparks et al., 1976; Wood, 1986), tree age or size (Sparks and Payne, 1978), nutritional status (Smith and Cotten, 1985; Sullivan and Herrera, 1981; Wood, 1986), and crop load the previous season (Smith and Cotton, 1985; Smith et al., 1993; Wood, 1986, 1989a).

Cold damage to pecan trees occurs in the autumn before they have cold-acclimated (Madden, 1978; Smith et al., 1993; Sullivan and Herrera, 1981), during winter dormancy (Cochran, 1930; Payne and Sparks, 1978; Wood, 1986), or in the spring (Madden, 1980; Malstrom et al., 1982) after growth processes are initiated. Different symptoms may be expressed depending on timing of injury. The following symptoms are typically used to diagnose cold injury: 1) longitudinal splitting of bark on the trunk, scaffolds, and small limbs induced by sunscald; 2) separation of bark from wood; 3) sunken areas on limbs and shoots appearing in the growing season; 4) death and browning of the cambium, inner bark, and phloem; 5) sporadic death of small

\footnotetext{
Received for publication 31 Mar. 2000. Accepted for publication 27 July 2000. The cost of publishing this paper was defrayed in part by the payment of page charges. Under postal regulations, this paper therefore must be hereby marked advertisement solely to indicate this fact.

${ }^{1}$ To whom requests for reprints should be addressed. E-mail address: bwood@byronresearch.net
}

shoots randomly located throughout the canopy; 6) delayed budbreak; 7) relatively sparse canopy; 8) resprouting from the root collar or from large wood below damaged scaffold limbs; and 9) splitting and browning of the inner bark and phloem of the rootstock (Sparks and Payne, 1978; Wood, 1989b). Cold injury to trunks is often exhibited by a dark, watery, sour-smelling liquid occurring beneath injured bark just above the ground on the south side of the trunk (Stuckey and Kyle, 1925).

"Sudden tree decline or death" (STD/D) occasionally is observed in pecan orchards shortly after spring budbreak. Because associated symptoms are atypical of injury by cold, the cause of STD/D is uncertain, raising questions as to how to protect against future losses. This report describes tree and temperature conditions that produced sudden decline and death of bearing pecan trees and proposes that STD/D is an atypical and subtle form of cold injury.

\section{Materials and Methods}

Affected orchard. SIDs are notoriously difficult to study because of their innate unpredictability; thus, replicated year-to-year study is either impossible or impractical. A SID became evident by early Spring 1998 in an orchard of 11-year-old 'Cheyenne' pecan on seedling rootstocks of open-pollinated 'Elliott'. Winter maximum and minimum daily air temperatures were available from a nearby weather station. Historical weather data also were available.

All trees were growing on a Faceville sandy loam soil (siliceous thermic Typic Paleudult), spaced on a 9-m square, and were managed according to Georgia Extension Service recommendations for fertility and pests (Crocker, 1996; Ellis et al., 1994). Drip irrigation had been used according to a "rule-of-thumb sys- tem" for scheduling using pan evaporation (Daniell, 1989), where water was applied based on average daily evaporation for the previous week, with the drip system operating daily for different time intervals, unless rainfall was $>1.3 \mathrm{~cm} \cdot \mathrm{d}^{-1}$ and the system was turned off for $3 \mathrm{~d}$. Trees typically received $\approx 170 \mathrm{~L}$ of $\mathrm{H}_{2} \mathrm{O}$ per tree per day via drip irrigation from September through October, but lesser amounts from May through August, when rainfall was more common. Trees typically exhibited midafternoon stomatal conductance to $\mathrm{H}_{2} \mathrm{O}$ vapor of $\approx 1.2-2.0 \mathrm{~mol} \cdot \mathrm{m}^{-2} \cdot \mathrm{s}^{-1}$. The orchard received annual broadcast applications of fertilizers to provide $\approx 220 \mathrm{~kg} \cdot \mathrm{ha}^{-1}$ of $\mathrm{N}, \mathrm{P}$, and $\mathrm{K}$, based on analyses of leaf samples taken according to standard methods (O'Barr et al., 1989). A problem with tree health became apparent at budbreak in early April.

Measured parameters. The previous season's crop load and leaf retention data were available for damaged and undamaged trees. Nut-meat yield was derived from the product of total nuts and average percentage of kernel per tree and was indexed to trunk cross-sectional area (TCA). The TCA was based on circumference $1 \mathrm{~m}$ above the soil line in early Apr. 1998. Leaf retention the previous October was based on percentage of leaflets retained by compound leaves, as determined from 10 terminal shoots sampled from the lower exterior of the eastern exposed canopy $(<\approx 3 \mathrm{~m}$ from the ground). Premature defoliation appeared to be due largely to feeding by the pecan leaf scorch mite [Eotetranychus hicoriae (McGregor)]

While making preparations for an unrelated study on these trees, a limited survey in early February identified two dead trees. These two trees later became part of the population of dead trees detected at budbreak when several 'Cheyenne' trees exhibited aberrant phenology ( $\approx 1$ Apr. 1998). About 50 trees exhibited dead buds and/or abnormal budbreak patterns, thus allowing segregation of trees into three vigor classes: 1) normal; 2) declining; and 3) dead. No affected trees occurred in the two outside rows of the orchard, but were otherwise randomly located throughout the orchard. Ten trees from each of the three classes were subsequently studied throughout the growing season for growth-related characteristics. The "normal" trees selected as controls were adjacent to either dead or declining trees.

Leaf area and shoot measurements were made in mid-May on 10 trees from each vigor class. Area was based on summation of all compound leaves from 10 terminals collected from both the lower and upper halves of the tree canopy. Measurement was by a LI-3000 Area Meter (LI-COR, Lincoln, Nebr.). The length of these terminal shoots was also measured.

Both 1-year-old shoots and small roots $(<0.50-\mathrm{cm}$ diameter $)$ of all three vigor classes were sampled randomly for determination of starch and total free sugars according to the methods of Wood and McMeans (1982) for pecan tissues. Roots were sampled in early April from beneath the drip-line and up to a depth of $16 \mathrm{~cm}$ in the soil profile. Excavated 
roots were segregated into three classes by diameter: large, 5-10 cm; small, 2-4 cm; and $<2 \mathrm{~cm}$. Sections of the root specimens (10 per root class per tree) were surface-sterilized, aseptically placed on potato dextrose agar (PDA), and incubated at $24^{\circ} \mathrm{C}$ for $7-10 \mathrm{~d}$. Fungal colonies that developed were identified as to genus.

Canopy budbreak patterns of "normal" and "declining" trees were measured for 10 trees of each class in late April. The percentage of terminal shoots displaying foliage was estimated by counting $\approx 30$ terminals within each vertical quarter-section of canopy (i.e., basal limb to $25 \%, 26 \%$ to $50 \%, 51 \%$ to $75 \%$, and $>75 \%$ of distance up the canopy).

Leaves were sampled from 10 trees of each vigor class in mid-July for comparison of nutrient element concentrations. Sampling was accomplished by collecting middle leaflet pairs from the middle compound leaf of 20 terminals located in the lower half of the canopy. The foliage had not received sprays of pesticides or zinc. Foliage was washed with deionized water, dried at $60{ }^{\circ} \mathrm{C}$, ground, and analyzed for standard macro and micro nutrients by the Univ. of Georgia Plant and Soil Testing Laboratory (Athens, Ga.) using standard techniques for analysis of cations and $\mathrm{N}$ in plant leaf samples.

Trees were rated in early May for degree of decline and ratings regressed against either percentage defoliation or nut yield. Decline categories, based on the condition of buds in the top half of the tree, were: $1=$ normal budbreak, no delayed or dead terminal buds; $2=1 \%$ to $25 \%$ of terminal buds killed; $3=26 \%$ to $50 \%$ of terminal buds killed; $4=51 \%$ to $75 \%$ of terminal buds killed, $5=76 \%$ to $99 \%$ of terminal buds killed; and $6=$ totally dead.

Statistical analyses were by SAS-ANOVA (SAS Institute, Cary, N.C.) and curves were fitted using TableCurve (Jandel Scientific, San Rafael, Calif.).

\section{Results}

The occurrence of cold damage to pecan trees is almost always clearly associated with a single severe drop in air temperature during the autumn, winter, or spring. This was not apparent in the present case. Comparison of daily maximum and minimum air temperatures during the 1997-98 dormant season with that of the historical record at the location indicated that autumn temperatures were within normal bounds. Specifically, the low daily temperature was $\geq 4{ }^{\circ} \mathrm{C}$ until a sudden drop occurred from a daily high of $15^{\circ} \mathrm{C}$ to a low of $-3^{\circ} \mathrm{C}$ on 15 and 16 Nov. (Fig. 1). Foliage had largely senescened and was $\approx 1$ week away from complete defoliation. While autumn cold damage to pecan has been reported to occur at $-12{ }^{\circ} \mathrm{C}$ when trees were exposed on 2 Nov. in Oklahoma (Smith et al., 1993) and at $-10{ }^{\circ} \mathrm{C}$ on 22 Oct. in New Mexico (personal observation), damage at temperatures as high as $-3^{\circ} \mathrm{C}$ during late fall have not been reported. Although the brief ( $\approx 16 \mathrm{~h}$ over two nights) exposure to $-3{ }^{\circ} \mathrm{C}$ could have damaged shoots, it is

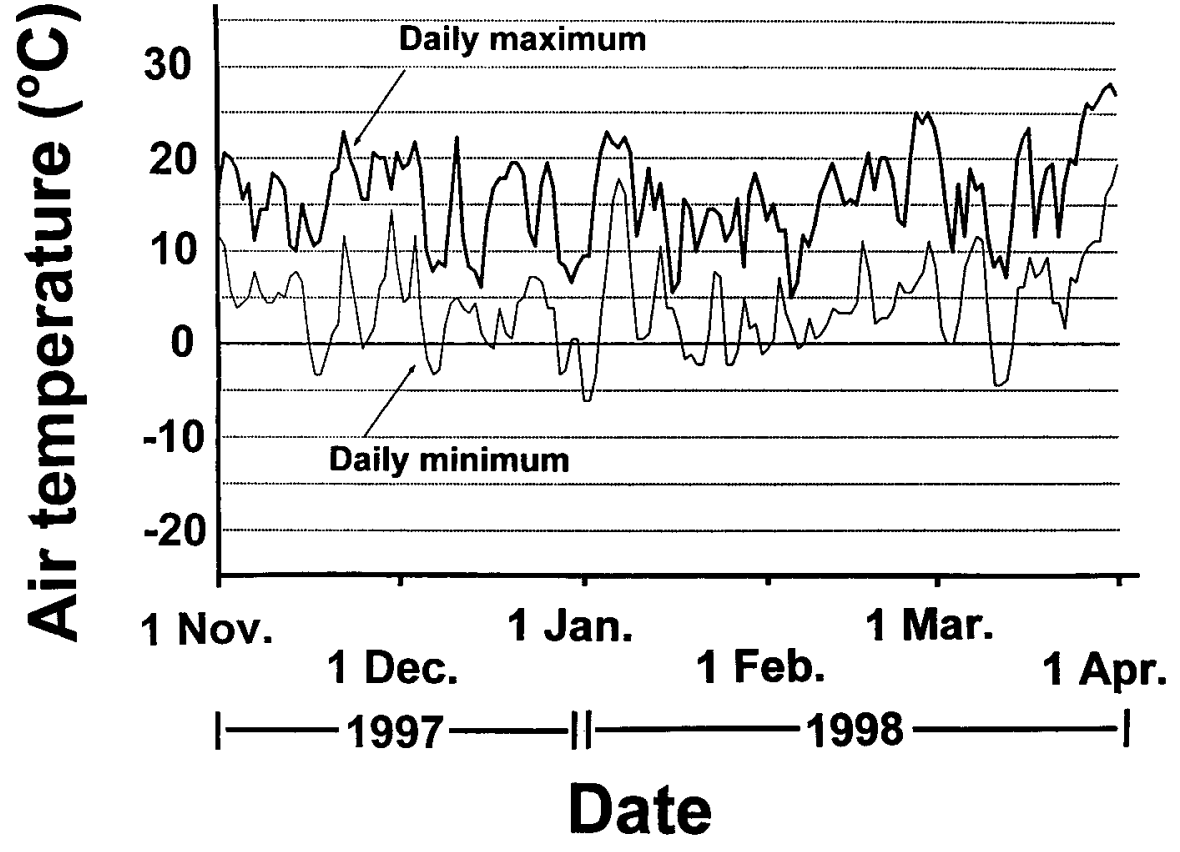

Fig. 1. Daily maximum and minimum air temperatures in a 'Cheyenne' pecan orchard in which trees exhibited cold damage during Winter 1997-98.

highly improbable that it would have injured roots, especially those insulated by several centimeters of soil. The autumn also produced a second brief cold period with low daily temperatures of $-3^{\circ} \mathrm{C}$ in early December, long after leaf fall.

Comparison of the winter months of the 1997-98 dormant season to those of the historical record indicated that the frequency and magnitude of temperature extremes were also within normal bounds for the orchard location (data not included). There were $17 \mathrm{~d}$ of below-freezing temperatures during Winter 1997-98 (Fig. 1). The winter's lows were -6 ${ }^{\circ} \mathrm{C}$ in early January and $-5^{\circ} \mathrm{C}$ in early March, $\approx 3$ weeks prior to budbreak. Midwinter lows were well within the range typically experienced at the orchard location and compare to a low of $-8^{\circ} \mathrm{C}$ in January of the previous dormant season, when STD/D was absent and individual trees had much better retention of foliage (data not included). 'Cheyenne' trees of similar age in an adjacent orchard were killed by winter cold in 1983-84 and 1984-85 when December and January temperatures dropped to -16 and $-21^{\circ} \mathrm{C}$, respectively.

The Spring 1997-98 dormant season was unusually warm with no freezing temperatures from early February until a sudden freeze on 13 Mar. when temperatures plummeted from a high daily temperature of $17^{\circ} \mathrm{C}$ to lows of $-5{ }^{\circ} \mathrm{C}$ on three consecutive nights, with daily highs being $\approx 8$ to $9{ }^{\circ} \mathrm{C}$ (Fig. 1). Pecan buds had enlarged by this time and were susceptible to damage by cold. Because the lower buds of bearing pecan trees typically enlarge and break before those in the upper canopy, the former would have been most susceptible to cold damage and also exhibited damage.

Tree death and low vigor, or decline, in Spring 1998 affected $\approx 20 \%$ of the orchard's trees. Decline was apparent at budbreak, with severely affected trees failing to break bud and lesser affected trees displaying varying percentages of budbreak (Table 1). Conversely, nearly all previous season's shoots of normal trees displayed normal shoot and foliage growth regardless of canopy position. A few damaged trees failed to break bud and were obviously dead at the time of budbreak, yet had been alive upon entering dormancy. The serendipitous detection of the death of two of these trees by late January indicated that the cold weather that caused death occurred much earlier. Budbreak was substantially less in declining trees, regardless of canopy position. Most new shoots within the lower canopy of affected trees died within $\approx 2$ weeks. This produced an obvious and distinct gradient in the number and vigor of vegetative organs from bottom to top of the tree. There was substantially less vegetative development in tree positions closest to the root system, resulting in the lower canopy being dead or thinly foliated while the extreme upper canopy displayed considerably more vegetative development, yet notably less vigor, than did normal trees. The inner bark and phloem tissue of the main trunk of damaged trees was relatively dry and light tan in color.

Leaf area and shoot length of emerging growth was reduced on decline-affected trees (Table 1). This was true in both the lower and upper canopy and was visually obvious even in midsummer, well after completion of leaf expansion. Nutrient element concentrations in foliage from declining trees was higher for most essential elements, such as N, P, K, and $\mathrm{Mg}, \mathrm{Mn}, \mathrm{Fe}$, and $\mathrm{B}$, but $\mathrm{Ca}, \mathrm{Al}, \mathrm{Cu}$ and $\mathrm{Zn}$ (Table 2) concentrations were not affected. This increased concentration is probably a 
Table 1. Budbreak pattern, leaf area, and shoot length within the canopy of normal and STD/D-affected trees. $^{\mathrm{z}}$

\begin{tabular}{lcr}
\hline \hline & \multicolumn{2}{c}{ Tree status } \\
\cline { 2 - 3 } Observations & Normal & Declining \\
\hline \multicolumn{2}{c}{ Terminals displaying foliage $(\%)^{y}$} \\
Lowest 25\% & $94 \mathrm{a}$ & $1 \mathrm{~b}$ \\
Next 25\% & $97 \mathrm{a}$ & $17 \mathrm{~b}$ \\
Next 25\% & $100 \mathrm{a}$ & $31 \mathrm{~b}$ \\
Highest 25\% & $100 \mathrm{a}$ & $81 \mathrm{~b}$ \\
\multicolumn{4}{c}{ Total leaf area $\left(\mathrm{cm}^{2}\right)^{x}$} \\
Lower canopy & $1311 \mathrm{a}$ & $271 \mathrm{~b}$ \\
Upper canopy & $1173 \mathrm{a}$ & $549 \mathrm{~b}$ \\
\multicolumn{3}{c}{ Shoot length $\left(\mathrm{cm}^{x}\right.$} \\
Lower canopy \\
Upper canopy & $17 \mathrm{a}$ & $3 \mathrm{~b}$ \\
\hline
\end{tabular}

${ }^{\mathrm{z}}$ Mean separation within rows by $\mathrm{F}$ test $(P=0.05)$.

${ }^{\mathrm{y}}$ Measured in late April.

${ }^{\mathrm{x}}$ Measured in late May.

result of a reduction in leaf area and therefore more nutrients available to the foliage.

Essentially all roots excavated from trees not breaking bud were dead (Table 3). They displayed abnormal dark brown coloration and a faint odor of ethanol. Declining trees (i.e., exhibiting both reduced vegetive vigor and budbreak) displayed far fewer living roots than did normal trees. Examination and culture of dead/dying roots and shoots from both affected and normal trees did not implicate fungi or bacteria as causal factors (i.e., only secondary fungi were detected; data not shown). The roots of nondamaged trees appeared healthy and normal, yet produced a variety of fungi in the isolation samples (data not shown). Similar fungi were detected in all root samples, regardless of damage class. Trichoderma and Fusarium were the genera most frequently isolated.

The concentration of total free sugars and starch in previous season's shoots was $\approx 41 \%$ of normal in declining trees and $\approx 5 \%$ of normal in dead trees (Table 3). Starch exhibited a similar pattern, with shoots from declining trees containing $\approx 62 \%$ of the normal concentration, whereas those of dead trees contained $\approx 41 \%$ of normal. A similar pattern also existed for total free sugars and starch in small roots (Table 3). Roots of dead trees had no detectable sugar or starch, whereas declining trees exhibited $\approx 25 \%$ and $\approx 47 \%$ as much sugar and starch as did normal trees. Thus, dead and severely declining trees had little or no free sugars or starch in either shoots or roots, even though there had been little or no new vegetative growth to consume photoassimilate reserves from either tissue. Neither the scion nor rootstock of apparently dead trees had regenerated sprouts by the end of the growing season.

The severity of damage was closely associated with crop load and the amount of foliage comprising the canopy from the previous growing season (Fig. 2). Trees with crop size reduced by mechanical fruit thinning the previous growing season (Smith and Gallott, 1990) exhibited little or no decline (i.e., no damage vs. $26 \%$ to $50 \%$ of shoots killed in nonthinned trees). Trees with heavy

Table 2. Nutrient element status of foliage from STD/D trees during shoot elongation and leaf expansion (mid-July). ${ }^{\mathrm{z}}$

\begin{tabular}{|c|c|c|c|c|c|c|c|c|c|c|c|}
\hline \multirow[b]{3}{*}{ Treatment } & \multicolumn{11}{|c|}{ Nutrient element } \\
\hline & \multicolumn{5}{|c|}{$\% \mathrm{DW}$} & \multicolumn{6}{|c|}{$\mathrm{mg} \cdot \mathrm{kg}^{-1} \mathrm{DW}$} \\
\hline & $\mathrm{N}$ & $\mathrm{P}$ & $\mathrm{K}$ & $\mathrm{Ca}$ & $\mathrm{Mg}$ & $\mathrm{Mn}$ & $\mathrm{Fe}$ & $\mathrm{Al}$ & $\mathrm{B}$ & $\mathrm{Cu}$ & $\mathrm{Zn}$ \\
\hline Healthy & $3.2 \mathrm{~b}$ & $0.2 \mathrm{~b}$ & $1.2 \mathrm{~b}$ & $1.1 \mathrm{a}$ & $0.4 \mathrm{~b}$ & $1411 b$ & $35 \mathrm{~b}$ & $177 \mathrm{a}$ & $25 \mathrm{~b}$ & $13 \mathrm{a}$ & $130 \mathrm{a}$ \\
\hline Declining & $3.9 \mathrm{a}$ & $0.3 \mathrm{a}$ & $1.4 \mathrm{a}$ & $1.1 \mathrm{a}$ & $0.5 \mathrm{a}$ & $1571 \mathrm{a}$ & $40 \mathrm{a}$ & $169 \mathrm{a}$ & $29 \mathrm{a}$ & $13 \mathrm{a}$ & $111 a$ \\
\hline
\end{tabular}

${ }^{\mathrm{z}}$ Mean separation within columns by $\mathrm{F}$ test $(P=0.05)$.

Table 3. Percentage of living roots and total free sugar and starch levels (based on dry weight) in previous season shoots and small roots of 'Cheyenne' pecan trees affected by STD/D. ${ }^{\mathrm{z}}$

\begin{tabular}{lccccc}
\hline \hline & & \multicolumn{2}{c}{ Shoots } & \multicolumn{2}{c}{ Roots } \\
\cline { 3 - 6 } Tree & $\begin{array}{c}\text { Live roots } \\
(\%)\end{array}$ & $\begin{array}{c}\text { Free sugar } \\
\left(\mathrm{mg} \cdot \mathrm{g}^{-1}\right)^{\mathrm{y}}\end{array}$ & $\begin{array}{c}\text { Starch } \\
\left(\mathrm{mg} \cdot \mathrm{g}^{-1}\right)\end{array}$ & $\begin{array}{c}\text { Free sugar } \\
\left(\mathrm{mg} \cdot \mathrm{g}^{-1}\right)\end{array}$ & $\begin{array}{c}\text { Starch } \\
\left(\mathrm{mg} \cdot \mathrm{g}^{-1}\right)\end{array}$ \\
status & $94 \mathrm{a}$ & $87 \mathrm{a}$ & $56 \mathrm{a}$ & $345 \mathrm{a}$ & $63 \mathrm{a}$ \\
Normal & $36 \mathrm{~b}$ & $36 \mathrm{~b}$ & $34 \mathrm{~b}$ & $85 \mathrm{~b}$ & $30 \mathrm{~b}$ \\
Declining & $2 \mathrm{c}$ & $4 \mathrm{c}$ & $23 \mathrm{c}$ & $0 \mathrm{c}$ & $0 \mathrm{c}$ \\
Dead & & &
\end{tabular}

${ }^{2}$ Mean separation within columns by Duncan's new multiple range test $(P=0.05)$.

crops generally exhibited considerable damage. The degree of damage $(y=$ damage class) increased sigmoidally $\{y=a+b /[1+$ $\exp -(x-c) / d]\} ;$ where $a=0.60, b=4.39$, $c=23.90, d=6.25 ; r^{2}=0.78$, as tree yield increased (i.e., $x=$ grams of kernel per $\mathrm{cm}^{2}$ of TCA) (Fig. 1A) and as the percentage of foliage remaining on the tree in mid-October decreased $(a=0.24, b=26.45, c=-70.12$, $d=-46.92 ; r^{2}=0.83$ ) (Fig. 1B).

\section{Discussion}

Death and decline of trees due to cold damage can produce serious economic losses. Because cold injury is a sudden infrequent disturbance to orchards, a priori study is not usually feasible. Certain symptoms exhibited by affected trees in the present study are the same as those generally accepted as symptomatic of trees injured by winter cold (Sparks and Payne, 1978; Wood, 1989b), i.e., delayed budbreak and death or stunting of new vegetative growth. However, trees in this study did not display symptoms typical of "cold damage" as mentioned in the introduction.

The severity of damage and symptoms exhibited by trees in the present study indicate two distinct cold damage events. The symptoms of canopy and root death (i.e., roots deep within the soil profile) appearing by early February suggest that death resulted from "autumn cold" (i.e., 15 Nov.) and its interaction with depleted levels of photoassimilate reserves due to heavy cropping and poor foliar health at the time of the freeze. The likelihood of this damage being due to "winter cold" appears remote since low daily temperatures during winter were not unusually cold (i.e., $-6^{\circ} \mathrm{C}$ ), nowhere near the -16 and $-21{ }^{\circ} \mathrm{C}$ temperatures that had killed nearby 'Cheyenne' trees a few years earlier (Wood, 1986). The "bottom-to-top-ofcanopy" gradient reductions in budbreak, bud death, and vegetative vigor is consistent with an interaction between depleted photoassimilate reserves within shoots and that of exposure to severe "spring cold" (i.e., $-5{ }^{\circ} \mathrm{C}$ ) in mid-March of an abnormally warm spring.
The close linkage between previous season's crop load and susceptibility to damage by cold confirms previous observations by Wood (1986) and Smith et al. (1993) and that crop load plays a key role in the physiology of cold acclimation of shoots and buds. A combination of heavy crop and premature defoliation appears to stress trees sufficiently to: 1 ) prevent the accumulation of assimilate reserves necessary for maintaining live roots throughout the dormant season; and 2) interfere with proper cold acclimation of shoot tissues.

The trees were beginning to crowd; thus, interior trees were beginning to be exposed to excessive inter-tree shading. Note that the upper canopy of these trees received good light exposure the previous growing season; thus, they probably had higher levels of carbohydrate reserves than did shoots in the shaded lower canopy. This difference in reserves undoubtedly contributed to greater growth, and perhaps also to better cold acclimation, in the upper canopy. Also noteworthy was that the two rows of trees at the orchard's perimeter, which received more sunlight than those in the interior of the orchard, included no dead or declining trees. This indicates that good exposure to sunlight can be a key factor in preventing cold damage.

The type of damage exhibited by 'Cheyenne' in the present study suggests that pecan trees, especially when prematurely defoliated by autumn freezes, can enter the dormant season in a visually healthy state, but subsequently die before spring because of insufficient root carbohydrate reserves. This likelihood may be enhanced in severely alternate-bearing cultivars since roots of "on" trees can have substantially reduced carbohydrate reserves (Wood, 1989a). Because pecan roots respire and grow periodically during the dormant season (White and Edwards, 1981), factors that reduce carbohydrate reserves (e.g., heavy cropping and premature defoliation) apparently can trigger events that eventually lead to tree death. Similarly, such factors also reduce carbohydrate reserves in shoots, especially in the 


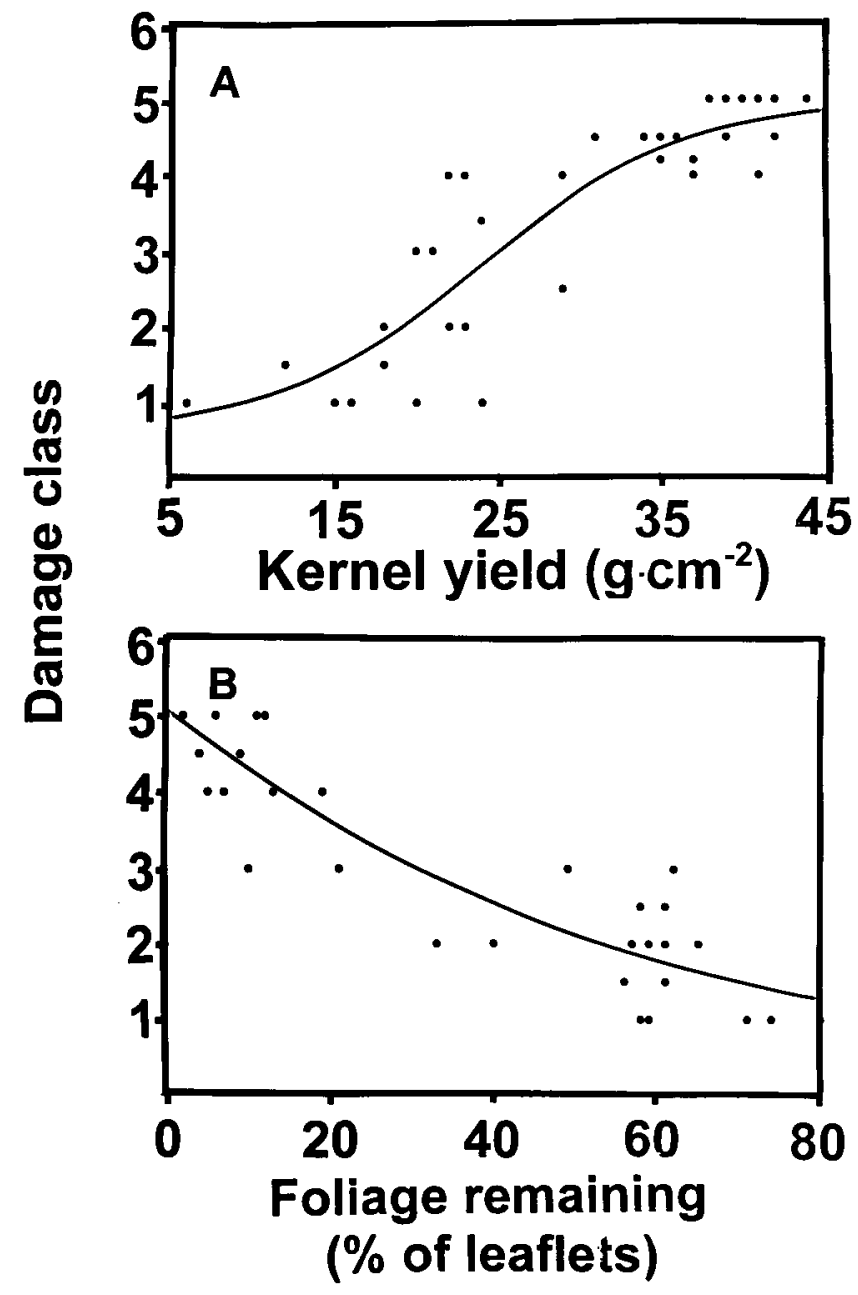

Fig. 2. Damage to bearing 'Cheyenne' pecan trees as related to previous season's nut yield (A) and degree of foliation in mid-October (B). Damage classes were: $1=$ normal budbreak, no delayed or dead terminal buds; $2=1 \%$ to $25 \%$ of terminal buds killed; $3=26 \%$ to $50 \%$ of terminal buds killed; $4=51 \%$ to $75 \%$ of terminal buds killed, $5=76 \%$ to $99 \%$ of terminal buds killed; and $6=$ dead tree, buds and roots dead. In 'A', $y=a+b /(1+\exp (-(x-c) / d))$, where $y=$ damage class, $x=$ nut yield in grams of kernel per $\mathrm{cm}^{2}$ of trunk cross-sectional area, $a=0.60, b=4.39, c=23.90, d=6.25$; and $r^{2}=0.78$. In 'B', the equation is also sigmoidal with $x=$ the percentage of foliage remaining on the tree in mid-October, $a=0.24, b=$ $26.45, c=-70.12, d=-46.92 ; r^{2}=0.83$.

excessively shaded and assimilate-stressed lower canopy, and probably prevent proper cold acclimation, resulting in subsequent death due to subfreezing temperatures or to pathogens. Fungi do not appear as factors in the decline of the tree roots, in that no one genus appeared dominant in "declining" or "dead" trees, and "normal" trees contained the same fungi as affected trees.

While the innate nature of sudden infrequent disturbances, such as that associated with autumn and spring cold, typically precludes critical study and absolute identification of causal factors, circumstantial evidence indicates that the physiological

\section{Literature Cited}

Cochran, G.C. 1930. Winter injury of pecans. Natl. Pecan Assn. Bul. 29:78-83.

Crocker, T.F. 1996. Commercial pecan production in Georgia. Univ. of Ga. Coop. Ext. Serv. Bul. 609.

Dale, V.H., A.E. Lugo, J.A. MacMahon, and S.T.A. Pickett. 1998. Ecosystem management in the context of large, infrequent disturbances. Ecosystems 1:546-557.

Daniell, J.D. 1989. Irrigation, p. 73-85. In: W.D. Goff, J.R. McVay, and W.S. Gazaway (eds.). Pecan production in the southeast: A growers guide. Ala. Ext. Serv. ANR-459.

Ellis, H.C. P. Bertrand, T.F. Crocker, and S. Brown. 1994. Georgia pecan pest management guide. Ga. Coop. Ext. Serv. Bul. No. 841

Madden, G. 1978. Effect of winter injury. Pecan Quarterly 12:17

Madden, G. 1980. Late spring freeze in a pecan nursery as a function of variety. Pecan Quarterly 14:11.

Malstrom, H.L., J.R. Jones, and T.D. Riley. 1982. Influence of freeze damage on fruitfulness of the pecan. Pecan Quarterly 16:13-17

O'Barr, R.D., M. Smith, and G. Taylor. 1989. Pecan nutrition, p. 61-71. In: W.D. Goff, J.R. McVay, and W.S. Gazaway (eds.). Pecan production in the Southeast: A growers guide. Ala. Ext. Serv. ANR-459.

Payne, J.A. and D. Sparks. 1978. Winter injury of pecan varieties in the nursery. Pecan South 5:118-119.

Smith, M.W., J.A Anderson, and B.S. Parker. 1993. Cultivar and crop load influence cold damage of pecan. Fruit. Var. J. 47:214-218.

Smith, M.W. and B.C. Cotton. 1985. Relationship of leaf elemental concentrations and yield to cold damage of 'Western' pecan. HortScience 20:420-422.

Smith, M.W. and J.C. Gallott. 1990. Mechanical thinning of pecan fruit. HortScience 25:414-416.

Smith, M.W., W. Reid, B. Carroll, and B. Cheary. 1993. Mechanical fruit thinning influences fruit quality, yield, return fruit set, and cold injury of pecan. HortScience 28:1081-1084.

Sparks, D. and J.A. Payne. 1978. Winter injury in pecans: A review. Pecan South 5:56-88.

Sparks, D., J.A. Payne, and B.D. Horton. 1976. Effect of subfreezing temperatures on budbreak of pecan. HortScience 11:415-416.

Stuckey, H.P. and E.J. Kyle. 1925. Pecan growing. MacMillan, New York.

Sullivan, D.T. and E. Herrera. 1981. A follow-up of 1976 winter injury to Western Schley and Wichita pecan trees. Pecan South 15:11-14.

White, A.W. and J.H. Edwards. 1981. Soil profile distribution and seasonal growth of pecan roots. Proc. Southeastern Pecan Growers Assn. 74:4753.

Wood, B.W. 1986. Cold injury susceptibility of pecan as influenced by cultivar, carbohydrates, and crop load. HortScience 21:285-286.

Wood, B.W. 1989a. Pecan production responds to root carbohydrates and rootstock. J. Amer. Soc. Hort. Sci. 114:223-228.

Wood, B.W. 1989b. Cold injury, p. 49-51. In: W.D. Goff, J.R. McVay, and W.S. Gazaway (eds.). Pecan production in the Southeast: A growers guide. Ala. Ext. Serv. ANR 459.

Wood, B.W. and J.L. McMeans. 1982. Carbohydrates and fatty acids in developing pecan fruit. J. Amer. Soc. Hort. Sci. 107:47-50. 